\title{
Correction to: Measuring Guanxi quality in the workplace
}

\author{
MiaoHua Chen ${ }^{1}$. Olwen Bedford ${ }^{2}$
}

Accepted: 22 July 2021 / Published online: 5 August 2021

(c) Springer Science+Business Media, LLC, part of Springer Nature 2021

\section{Correction to: Journal of Business and Psychology https://doi.org/10.1007/s10869-021-09762-3}

Tables 1 and 2 should have no header as shown below:

The original article has been corrected.

Table 1 Terms related to Guanxi

\begin{tabular}{|c|c|c|}
\hline Renqing & Reciprocal favour & $\begin{array}{l}\text { A favour; Reciprocity norms encompassing a sense of obligation } \\
\text { to provide and return favours; emotional sensitivity to the needs } \\
\text { of the partner }\end{array}$ \\
\hline \multirow[t]{2}{*}{ Mianzi } & Face & A person's social status or reputation as perceived by others \\
\hline & Facework & $\begin{array}{l}\text { Willingness to give face to the partner (make them look good in } \\
\text { front of others), and to save their face (ensure they do not look } \\
\text { bad in front of others) }\end{array}$ \\
\hline Ganqing & Affection & Feeling of friendship and involvement in the partner's personal life \\
\hline Xinren & Trust & Confidence in the partner's reliability and trustworthiness \\
\hline
\end{tabular}

Table 2 Hypotheses

\begin{tabular}{|c|c|c|}
\hline H1 & Structural validity & Facework and reciprocal favour items combine to form a single dimension (renqing) \\
\hline $\mathrm{H} 2$ & Criterion-related validity & $\begin{array}{l}\text { The GQS has a significant positive correlation with each of } 3 \text { outcome variables: relational commitment, } \\
\text { trust in the partner's organization, and relational satisfaction }\end{array}$ \\
\hline H3 & Role of xinren & Xinren (trust) is better conceptualized in terms of a dimension of guanxi quality than as an outcome \\
\hline $\mathrm{H} 4$ & Convergent validity & The GQS has a positive correlation with existing uni- and multi-dimensional measures of workplace guanxi \\
\hline H5 & Incremental validity & The GQS outperforms the unidimensional measure in predicting each of the 3 outcome variables \\
\hline H6 & Incremental validity & The GQS outperforms the multidimensional measure in predicting each of the 3 outcome variables \\
\hline
\end{tabular}

Publisher's Note Springer Nature remains neutral with regard to jurisdictional claims in published maps and institutional affiliations.

The original article can be found online at https://doi.org/10.1007/ s10869-021-09762-3.

$\checkmark$ Olwen Bedford

olwen.bedford@gmail.com

1 Psychology Division, Nanyang Technological University, Singapore, Singapore

2 Department of Psychology, National Taiwan University, Roosevelt Road, Section 4, \#1, Taipei, Taiwan 